\title{
ロ腔癌の頸部リンパ節転移に関する臨床的，病理組織学的研究
}

\author{
草間幹夫・岸豊子・堀越勝・稲垣由香 \\ 阿部和夫・岩本紀久・榎本昭二
}

\section{Clinical and histopathological evaluation on cervical lymph node metastasis of oral cancer}

\author{
Mikio Kusama - Toyoko Kishi - Masaru Horikoshi \\ Yuka INAGAKI - Kazuo AbE • Norihisa Iwamoto \\ Shoji ENomoto
}

\begin{abstract}
Between 1981 and 1988, 148 total radical neck dissections (TND) were performed at the Department of Second Oral and Maxillofacial Surgery in Tokyo Medical and Dental University Hospital for initial patients with squamous cell carcinoma of the oral cavity and adjacent region.

Tongue cancer patients had metastatic lymph nodes most frequently in the upper deep cervical region, lower gingiva had metastases in the submandibular region, floor of the mouth had metastases in the upper deep cervical region and in the submandibular region, and upper jaw had metastases in the upper deep cervical region and contra lateral sites.

In this study of 148 determinate patients, the control rate was $65 \%$ when lymph nodes were histologically negative, $48.6 \%$ when one lymph node was positive, $43.5 \%$ when two lymph nodes were positive, $54.5 \%$ when three lymph nodes were positive, and $5.6 \%$ when four or more nodes were positive. Control rate was $65.4 \%$ for patients with lymph node involvement confined to the Level 1, $29 \%$ for patients with lymph node involvement confined to the Level 2, $33.3 \%$ for patients with spread of carcinoma to nodes in the Level 3, and $0 \%$ for patients with spread of carcinoma in the Level 4.

In histopathological findings in primary region, patients with mode of invasion of $4 \mathrm{C}, 4 \mathrm{D}$ resulted in poor prognosis, while in metastatic cervical region patients with mode of invasion of $4 \mathrm{D}$ were many and showed poor prognosis.

On the patterns of nodal involvement, the patients of entire node-metastatic type (Grade-D) and diffuse node-metastatic type (Grade-E) had poor prognosis. On the patterns of extranodal spread, the patients of extranodal invasion had poor prognosis.

On the histological differentiation in the primary and cervical region, the patients of Grade 3 resulted in poor prognosis.
\end{abstract}

Key words: oral cancer(口腔癌), cervical lymph node metastasis(頙部リンパ節転移), patterns of nodal involvement (リンパ節転移進展度)

東京医科鸼科大学药学部第 2 口膑外科学教空 （主任：榎本昭二教授）

The Second Department of Oral and Maxillofacial Surgery, Faculty of Dentistry, Tokyo Medical and Dental University (Chief: Prof. Shoji Enomoto)

受付日：平成 2 年 7 月 30 日 
緒

言

口腔癌は頸部りンパ節転移の頻度が高く、治療をする 上で頸部リンパ節転移の制御は成績向上のための重要な 要素である。 また，原発巣を一次病巣とすると頸部りン バ節が二次病巣となることが多く，その形部りンパ節を 詳細汇検討することは, 次に発生する可能性のある三次 病巣鬲るい:予後を推測する上で非常に有意義なことと 思わ机る。原発宩の臨床的および病理組織学的特徵之転 移との関係については多くの研究がなされてきたが，転 移巣の病態を十分に検討した報告は少ない。

今回，われわれは転移巣を臨床的および病理組織学的 に詳細に観察することにより，原発巣部位別の頸部りン 節転移部位, 転移 Level と個数, 術式と病理組織学的 転移, 浸潤様式, リン・゙節転移進展度と節外転移パター ン，病理組織学的分化度および予徭について検討したの で報告する。

\section{対象と研究方法}

対象:さ1981〜1988年の 8 年閒に当科て頸部郭清術を施 行した170例（延べ 186 例）のうち， 1 次症例（166例） で扁平上皮癌症例の 148 例とした（表 1).148例の部位

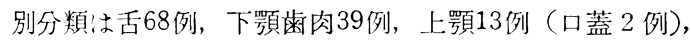
口底15例, 頓粘膜 7 例, 口峡咽頭 5 例および口唇 1 例で あった（表２）。

頸部郭清術施行態度別内訳江初回治療時治療的64例, 初回治療時予防的 42 例, および後発転移時 2 次的 42 例で 㐫った（表了）。

臨床的検討は，原発栄部位による頸部リンパ節転移部 位および Level 分類を行い，転移りンパ節総個数によ る比較を行った。 次汇病理組艟学的検討を行い, 病理組 織学的転移の有無, 転移リンハ節個数, Level 分類と子 後の関係について調査した。 また, 頸部郭清の術式（患 側および対側の術式）およびその病理組織学的転移の有 無と予後について検討した。

3 番目に, 病理組織学的浸潤様式を原発巣打よび転移 リンパ節で観察し，それぞれの相関，予後との関係につ いて検討した。次に，リンパ節転移進展度と節外転移パ ターンについて検討した。すなわち，I，リンパ節転移 進展度は，A，転移腫瘍が周縁洞に限局， B 。周縁洞か ら傍皮質や中間洞に浸潤，C．リンパ組織の約半分 $(1 / 3$ ２/3）が腫瘍に置換，D．リンバ組織の大半が腫瘍に 置换，E，リンパ組織の中に散在性に腫瘍が浸潤の $5 つ$ に分類し，II．節外転移パターンは，O．節内転移，1. 一部汇節外転移（被膜の $1 / 3$ 以下），2. リンパ節の約半 分 $(1 / 3 \sim 2 / 3)$ に節外転移，3. リンパ節の大半で節外 転移の 4 つに分類し，I，IIの組み合わせ（たとえば，
表 1 当科比扣计万頙部郭消術施行症例 内訳

(1981 1988年)

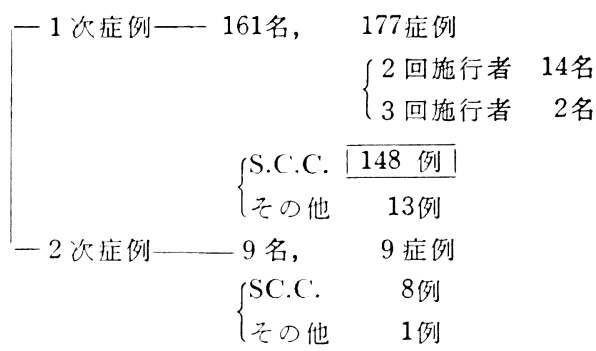

表 2 発拝部位別分煩

(1 次应例161例中 S.C.C. 症例)

\begin{tabular}{|c|c|}
\hline & S.C.C. (148例) \\
\hline 舌 & 68 \\
\hline 下 罘 & 39 \\
\hline $\begin{array}{l}\text { 上咢靧 } \\
\text { (口蓋) }\end{array}$ & $\begin{array}{c}13 \\
(2)\end{array}$ \\
\hline 口底 & 15 \\
\hline 頋粘膜 & 7 \\
\hline 口陕咽頭 & 5 \\
\hline 口唇 & 1 \\
\hline
\end{tabular}

表 3 頚部郭清得施行内訳

\begin{tabular}{|c|c|c|c|c|}
\hline & $\begin{array}{c}\text { 初回治療時 } \\
\text { 治療的 }\end{array}$ & $\begin{array}{c}\text { 初回治療時 } \\
\text { 予防的 }\end{array}$ & $\begin{array}{c}\text { 後発転移時 } \\
2 \text { 次的 }\end{array}$ & 計 \\
\hline I & $\gamma$ & 6 & 13 & 19 \\
\hline II & - & 18 & 22 & 40 \\
\hline $\mathbb{I I}\left(\mathrm{N}_{0}\right)$ & $\gamma$ & 9 & 6 & 15 \\
\hline $\mathbb{I I}(\mathrm{N} 1 \sim 3)$ & 29 & $\alpha$ & $\gamma$ & 29 \\
\hline $\mathbb{I V}\left(\mathrm{N}_{0}\right)$ & $\gamma$ & 9 & 1 & 10 \\
\hline $\mathrm{IV}(X 1 \sim 3)$ & 35 & $\gamma$ & $\alpha$ & 35 \\
\hline 計 & 64 & 42 & 42 & 148 \\
\hline
\end{tabular}

A-1，D-3 など）により転移を評価した（図1)。次に 上記の分類と転移りンパ節浸潤様式の関倸拉よび予後に ついて検討した。最後に, 病理組織学的分化度を原発巣 および転移巣について判定し，それと予後の関係につい て検討した。

\section{結果}

頸部郭清症例の原発巣部位別の頸部りンパ節転移部位 と頻度を総個数でみると, 舌では上内深頸 40 , 㴿下 21 , 中内深頸20, 下内深頸10の順であり, 上内深頸りンパ節 への転移の頻度が高く，顎下部，中内深頸りンハ節への 
Iリンバ節転移谁展傗:

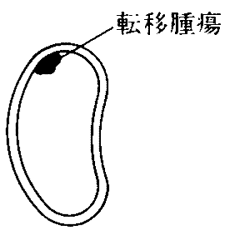

A

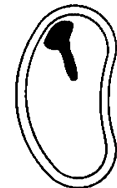

$\mathrm{B}$

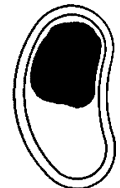

C

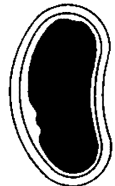

D

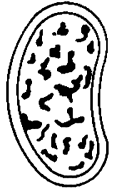

E
転移腫瘍が周縁 洞に限局
周縁洞から偻皮 質や中間洞!二浸 潤
リンバ組織の約 半分 $(1 / 3 \sim 2 / 3)$ か腫瘍に置換
リンパ組織の大 半か腫瘍に置換

リンバ組織の中 に散在:性に腫瘍 が浸潤

II 節外転移パターン

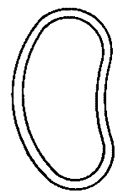

0

節内転移

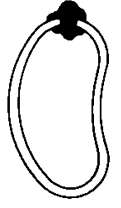

1

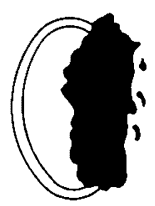

2

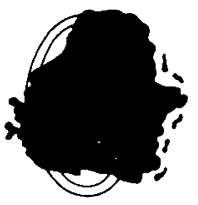

3

$\begin{array}{lll}\text { 一部に節外転移 } & \text { リンパ節の約半 } & \text { リンバ節の大半 } \\ \text { (被膜の } 1 / 3 \text { 以下 }) & \text { 分 }(1 / 3 \sim 2 / 3) に & \text { で節外転移 } \\ & \text { 節外転移 } & \end{array}$

図 1 リンパ節転移進展度扎よび節外転移パターン

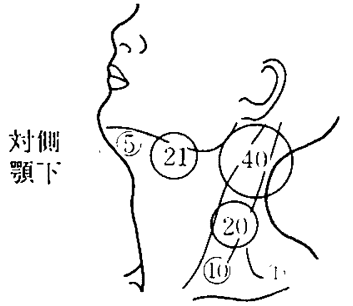

A. 企 $(68$ 例)

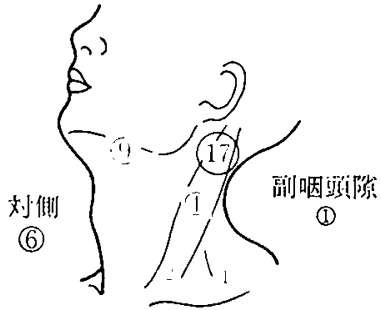

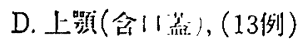

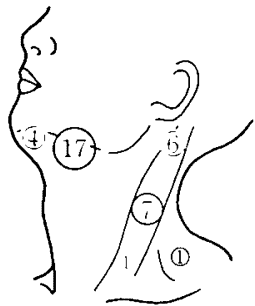

B. 下顎药闪 (39例)

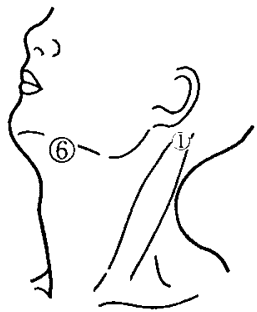

E. 煩粘脱 ( 7 例)

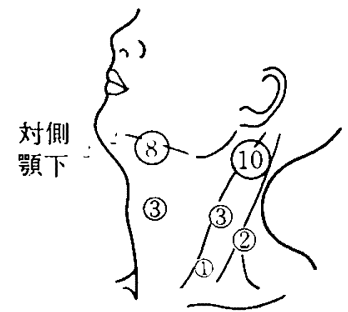

C. 口底(15例)

図 2 頸部郭清症例の原発樂部位別の頸部リンパ節転移部位と頻度（総個数） 
表 4 病理組織学的転移の部位, 個数と予後

\begin{tabular}{|c|c|c|c|c|c|c|}
\hline $\begin{array}{l}\text { 病理組繊 } \\
\text { 学的転移 }\end{array}$ & $\begin{array}{l}\text { 転移 } \\
\text { リン節 } \\
\text { 個数 }\end{array}$ & Level 1 & Level 2 & Level 3 & Level 4 & $\mathrm{Ao} /$ 症例数 \\
\hline \multirow{10}{*}{$P N(+)$} & 1 & $\begin{array}{l}00000 \\
00000 \\
00 \\
\times \times \times \times \times \\
\square\end{array}$ & $\begin{array}{l}00000 \\
\times \times \times \times \times \\
\times \times \times \times\end{array}$ & ${ }^{0} \times x \times$ & & $18 / 37$ \\
\hline & 2 & $\begin{array}{l}00000 \\
\times \times \\
\square\end{array}$ & $\begin{array}{l}00 \\
x \times x \times x \\
x\end{array}$ & $\begin{array}{l}000 \\
\times \times \times \times\end{array}$ & & $10 / 23$ \\
\hline & 3 & & $\begin{array}{l}00 \\
x \times x \times\end{array}$ & $\begin{array}{l}0000 \\
\times\end{array}$ & & $6 / 11$ \\
\hline & 4 & & $\triangle$ & $x$ & & $0 / 2$ \\
\hline & 5 & & & $\begin{array}{l}0 \\
x \times\end{array}$ & $x$ & $1 / 4$ \\
\hline & 6 & & & & $x$ & $0 / 1$ \\
\hline & 7 & & & $x \times$ & $x$ & $0 / 3$ \\
\hline & 8 & & $x \times$ & & & $0 / 2$ \\
\hline & 9 & & & $x$ & & $0 / 1$ \\
\hline & 10 以上 & & & $x \times x$ & 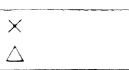 & $0 / 5$ \\
\hline \multicolumn{2}{|c|}{$\operatorname{PN}(-)$} & \multicolumn{4}{|c|}{$\begin{array}{l}0000000000 \\
0000000000 \\
0000000000 \\
0 \\
\times \times \times \times \times \times \times \times \times \times \\
\times \times \times \\
\square \square \\
\triangle\end{array}$} & $31 / 47$ \\
\hline & & & & & & $66 / 136$ \\
\hline
\end{tabular}

: Ao $\times$ : Dc $\square:$ Do $\triangle:$ Ac

転移がそれにつついていた（図2）。下顎歯肉では靧下 部が 17 と最も多く, 口底では上内深頸 10 , 顎下部 8 と上 内深頸，顎下の頻度が等しかった。一方，上顎(含口蓋) では上内深頸が17と最も多かったが，対側転移が6個あ ったことが特徵的であった。他に，頓粘膜は㴿下部が多 く，口陕咽頭は中内深頸りンパ節に転移が多かった。

病理組織学的転移の有無, 部位および個数を予後との 関係で検討すると，あきらかなもので PN $(+)$ が89例に 対して PN (一) が 47 例であった（表 4 ）. PN $(+$ ) 症例 を分析すると，転移リンパ節個数が 1 個か 2 個が 60 例 (64.4\%) と多く，3 個以内が 71 例 $(79.8 \%)$ と大部分 であった. Level 別に検討すると, Level 1 までが26例 (29. $2 \%)$, Level 2 までが 31 例 $(34.8 \%)$, Level 3 まで が27例 (30.3\%)，および Level 4 までが 5 例 (5.6\%) であり, Level 2 までが過半数であったが，かなり多く の症例で Level 3 までの転移があった。Ao 症例数/症例 数を制御率として比較すると, PN (一) 31/47 (66.0 $\%), \mathrm{PN}(+) 35 / 89(39.3 \%)$ であり, 個数別では, 転
移りンバ節個数 1 個が $18 / 37$ (48.6\%)， 2 個が $10 / 23$ (43.5\%)，3 個が6/11 (54.5\%)，4 個以上が $1 / 18$ (5.6 \%)であった。 Level 分類による制御率は Level 1 か 17/26 (65.4\%), Level 2 か $9 / 31$ (29.0\%), Level 3 が $9 / 27$ (33.3\%), および Level 4 が $0 / 5(0 \%)$ であり, Level 1 が高く, Level 4 が著明に低い結果であった。 た転移りンパ節個数が多い症例はと遠位 Level への転移 が多いようであった。

頸部郭清術式および病理細織学的転移と子徯について は患側 PN ( - ), 対側 PN ( - ) が最毛制御率が良く, 患側 $\mathrm{PN}(+)$, 対側 $\mathrm{PN}(-)$ が次で 33/77 (42.9\%), および患側 PN $(+)$, 健側 PN $(+)$ が2/8 (25.0\%) で あった（表 5 )。術式では患側全頸部郭清（TND）のみ の制御率は38/78 (48.7\%), 患側 $\mathrm{TND}$, 対側上頸部郭 清（UND）の制御率は27/48 (56.3\%) と後者が勝って いたが，両側に転移があったために雨側の頸部郭清を行 い, そのためにあきらかに救われた症例は 2 例のみであ った。 
表 5 颛部郭清訹式, 病理組織学的転移と予後

\begin{tabular}{|c|c|c|c|c|}
\hline $\begin{array}{l}\text { PN }(+,-) \\
\text { 頸部 } \\
\text { 郭掯術式 }\end{array}$ & $\begin{array}{c}\text { 患側 対側 } \\
\mathrm{PN}(-), \mathrm{PN}(-)\end{array}$ & $\begin{array}{c}\text { 患側 } \quad \text { 対側 } \\
\mathrm{PN}(+), \mathrm{PN}(-)\end{array}$ & 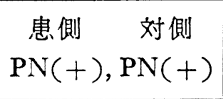 & $\mathrm{Ao} /$ 症例数 \\
\hline 患側 TND & $\begin{array}{l}000000 \\
000000 \\
0000000 \\
0 \\
\times \times \times \times \times \times \\
\times \times \\
\square\end{array}$ & $\begin{array}{l}000000 \\
000000 \\
000000 \\
0 \\
\times \times \times \times \times \times \\
\times \times \times \times \times \times \\
\times \times \times \times \times \times \\
\times \times \times \times \times \times \\
\times \times \times \times \times \times \\
\times \quad \\
\end{array}$ & & $38 / 78$ \\
\hline $\begin{array}{l}\text { 患側 TND } \\
\text { 対側 UND }\end{array}$ & $\begin{array}{l}000000 \\
00000 \\
\times \times \times \times \times x \\
\Delta \times\end{array}$ & $\begin{array}{l}000000 \\
000000 \\
00 \\
\times \times \times \times \times \times \\
\times \times \times \times\end{array}$ & $\begin{array}{l}00 \\
\times \times \\
\Delta\end{array}$ & $27 / 48$ \\
\hline 両側 $\mathrm{TND}$ & & $\times$ & $\times \times \times$ & $0 / 4$ \\
\hline 両側 UND & & $x$ & & $0 / 1$ \\
\hline 患側 UND & & $x$ & & $0 / 1$ \\
\hline $\mathrm{Ao} /$ 症例数 & $30 / 47$ & $33 / 77$ & $2 / 8$ & $65 / 132$ \\
\hline
\end{tabular}

表 6 原発集扣よび転移リンパ節の浸潤様式と予後

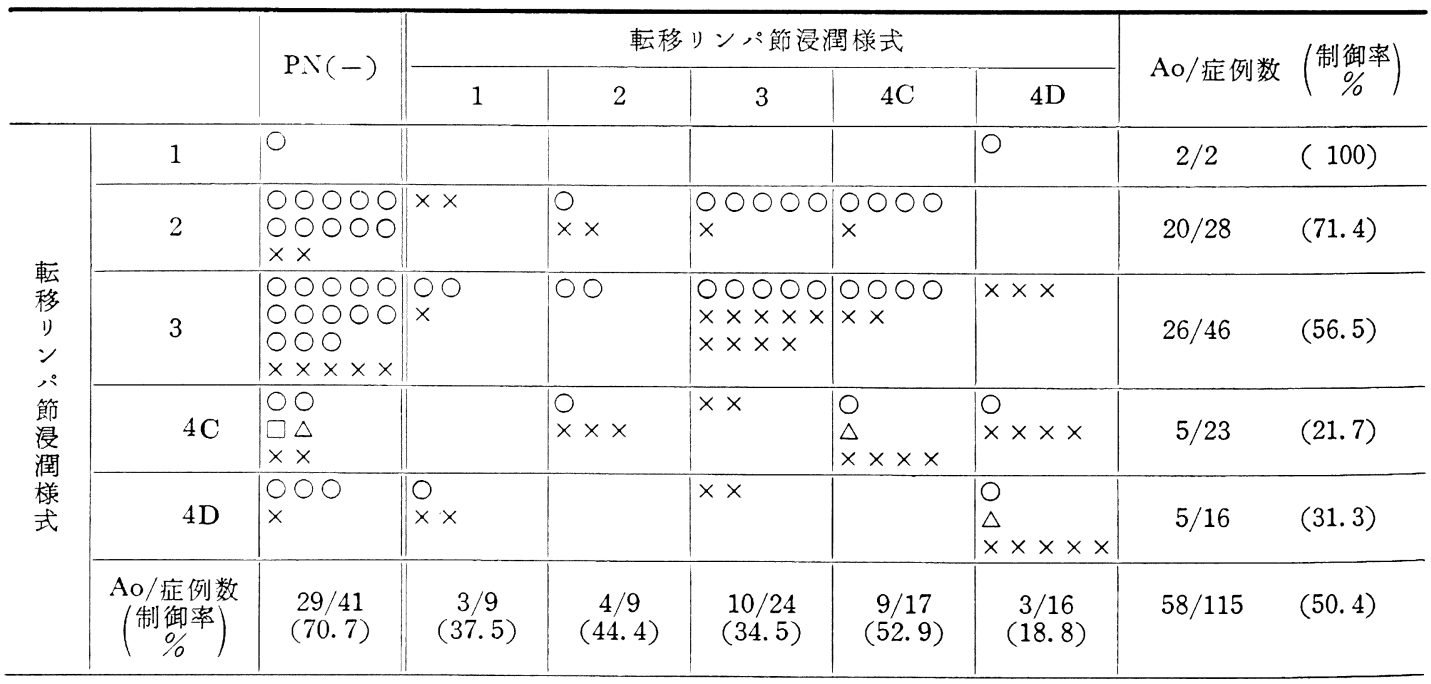

$\circ$ : Ao $\times$ : Dc $\square:$ Do $\triangle:$ Ac

病理組織学的浸潤様式と予後の関係を原発巣でみる 之, 原発巣では浸潤様式 3 型が最も多く, 次に $4 \mathrm{C}, 2$ の順であり，4D 型も比較的多かった（表 6 ）。制御率は 浸潤様式の程度が高い汪ど 低く，4C 型 21.7\% 4D 型 $31.3 \%$ であった。一方，転移巣では，浸潤様式 3 型が最
も多かったが，4C 型，4D 型が次に多かった。制御率 は浸潤様式の程度にかかわらず悪かったが，特に $4 \mathrm{D}$ 型 で18.8\%と低值であった。原発栄の浸潤様式と転移巣の それとは扮打むね相関するようであったが(写直 1，2）， 転移鉴で $4 \mathrm{D}$ 型が幾分多数であり，それらは予後も悪か 


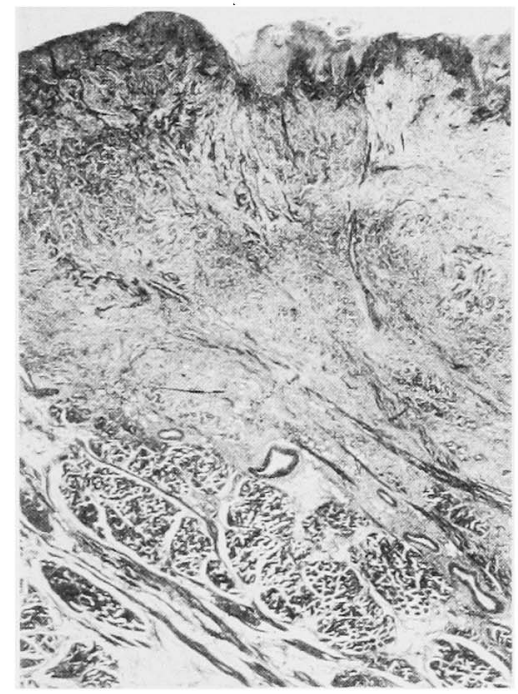

写真 1 浸潤様式 $4 \mathrm{D}$ 考示寸原発笨 舌扁平上皮癌 (T2N1Mi0) で, 分化度は Grade 3 を 示寸 $(\mathrm{H}-\mathrm{E}$ 染色, $\times 24)$.

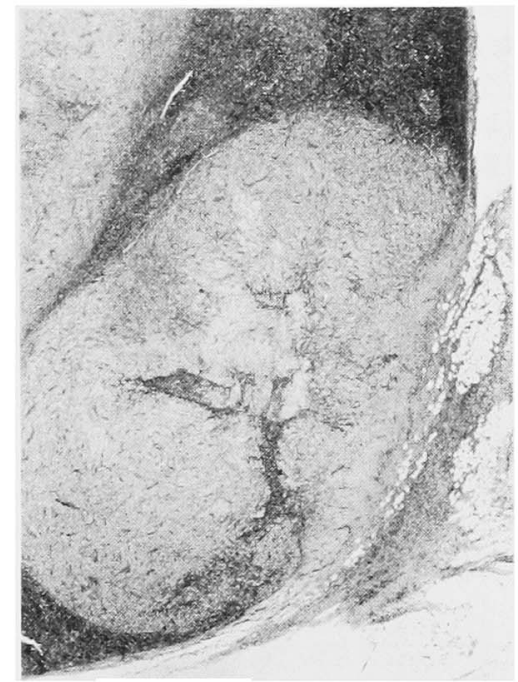

写真 2 写真 1 と同一症例の転移栄 浸潤様式は $4 \mathrm{D}$ (原発巣と同じ)を示す。リンパ節 転移進展度，節外転移バーーンは D-1 型を示す。右 方に節外転移がみられる。分化度は Grade $3(\mathrm{H}-\mathrm{E}$ 染色, $\times 24$ ).

った.

リンパ節転移進展度は多くの症例が D 型（写真 2 ） で, 次にE型 (写真3) であり，A型 (写直 4)、B型, C型（写真 5) はわずかであった（表 7)，予後は A， B , C型, 特に A-O 型 (写真 4)，B-O 型， C-O 型

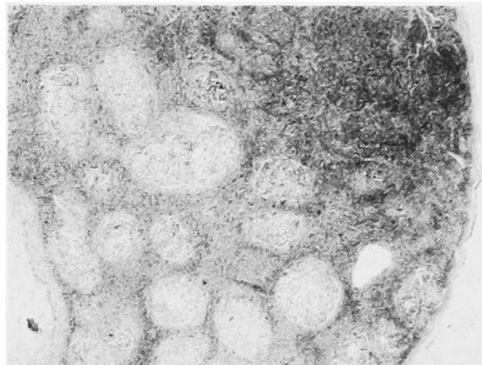

写真 3 リンパ節転移進展度 $\mathrm{E}$ 型を示 す転移栄

下顎齿肉扁平上皮癌（T4N3M0）で，浸潤様式 3 型， リンパ節転移進展度，節外転䔟バターンは $\mathrm{E}-\mathrm{O}$ 型, 分化度は Grade 2 を示す (H-E 染色， × 24).

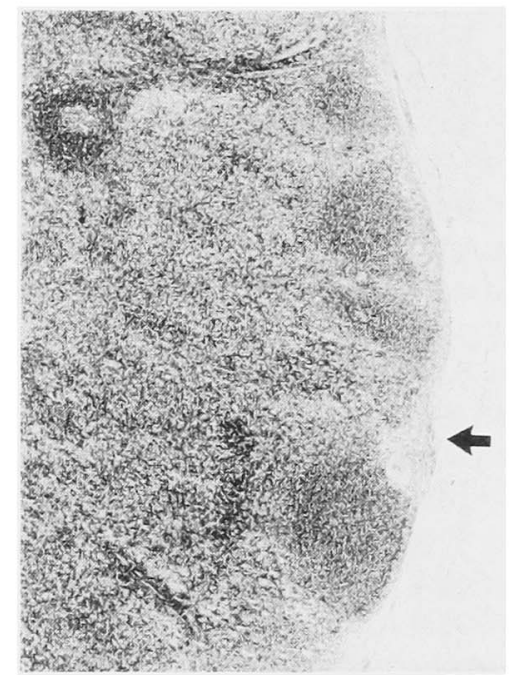

写真 4 リンパ節転移進展度 $\mathrm{A}$ 型の転移巣 舌扁平上皮癌 (T2NOMO) で, 浸潤様式 1 型（原発 栄は 3 型), リンパ節軽移進展度, 節外転移パター ンは A-O 型, 分化度は Grade 2 を示卞。右侧被膜 直下 (知印) にわずかに転移巣がみられる(H-E 染 色, $\times 24)$.

(写真 5) で良く，一方 $\mathrm{D}, \mathrm{E}$ 型は悪く，そのうちで D-2，D-3 型および E-2， E-3 型で特に悪いようであ った、転移りンパ節の浸潤様式による差は前述のごとく あきらかではなかったが，4D 型では予後は著明に悪く， リンパ節転移進展度・節外転移パターンが D-1（写真 2)，D-2，D-3 型すなわち，リンパ組織の大半が尰場 に置換し，節外浸潤を起こしたタイプで浸潤様式が $4 \mathrm{D}$ 型の10症例はいずれる予後が悪かった。

原発栄および転移栄の病理組織学的分化度 (UICC, 1987）を観察すると，原発巣，転移巣ともに Grade 2 （中等度分化） 称最多く，次に Grade 3 （低分化）が 
多く, Grade 3 の方が予後が悪い傾向であった（表 8$)$.

考察

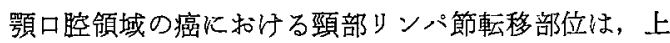
内深頸りンパ節が最も多く, 次に顎下リンパ節に多く，

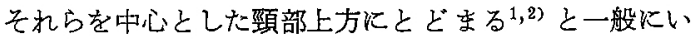
われているが，決してそのように単純ではなく，岡本3)， 篠原》)の報告の上うに，中内深頸部，下内深頸部などに 転移が起こることは频回にあり，当科汸ける検討で は，上内深頸部が多かったものの頸部全体に転移の可能 性があるという結果であった。しかし，そ机は部位によ り特徵的であった。すなわち，舌は最も転移の頻度が高 く，転移部位が多岐にわたっており，上内深頸部を中心 飞, 蓣下部, 中内深頸部, 下内深頸部, オトガイ下部, 鎖骨上窝，対側罘下部にみられた。下顎歯肉は比較的転 移の頻度が低く(5)，蕷下部が中心であったが，下内深頸 部，鎖骨上窩にみら机る症例も专った。底は舌と同様 に転移頻度が高く，上内深頸部之䫇下部が同程度に発現 し，また原発学発生部位が両側飞わたる症例があるた

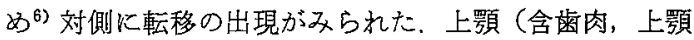
洞，口蓋）は上内深頸りンパ節転移の頻度が高く, 対側 転移も多くみられた。

転移リンパ節の個数と転移 Level との関係では，佐 藤》，岡本 ${ }^{3)}$ 之同様比，転移リンパ節が 1 個の症例は多 くが Level 1 と 2 亿限局していたが，個数が增加するに 従って, Level 3 あるいは Level 4 にも転移が多くみら
れた，予後に関しては PN( 一) 症例の約 $2 / 3$ は制御され ており，PN(+)症例では転移りンパ節が $1 〜 2$ 個で Level 1 亿限局した症例は制御されていたが，他は全体 に悪く, 結果的に治療的頸部郭清では対処の遅い症例が

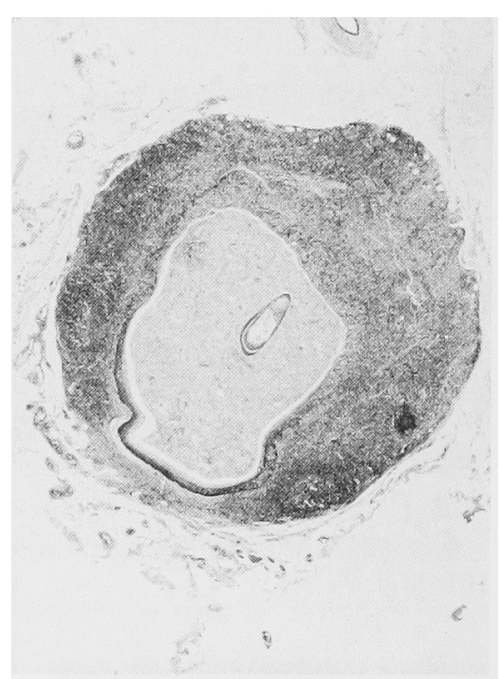

写真 5 リンパ節転移進展度，節外転移 バターン C-O 型を示す転移栄

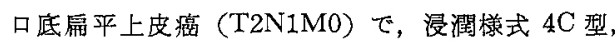
リンパ節転移進展度，節外転移パターン C-O 型, 分化度は Grade 2 を示す リンパ節の約 $1 / 2 か ゙$ 腫瘤 に置换されている(H-E染色，×24）。

表 7 リンパ節耺移進展度, 節外転移パターンと浸潤様式

\begin{tabular}{|c|c|c|c|c|c|c|c|c|c|c|c|c|c|c|c|}
\hline & \multicolumn{14}{|c|}{ リンパ節転移進展度と節外転移パターン } \\
\hline & & $\mathrm{A}-0$ & $3 \mid \mathrm{B}-0$ & \begin{tabular}{|c|c|}
$B 1-3$ & $C-0$ \\
\end{tabular} & $C-1$ & $C-2$ & $\mathrm{C}-3$ & $\mathrm{D}-0$ & $\mathrm{D}-1$ & $\mathrm{D}-2$ & $\mathrm{D}-3$ & $\mathrm{E}-0$ & $E-1$ & $\mathrm{E}-2$ & $E-3$ \\
\hline & & 0 & (c) & (Q) & $\theta$ & 0 & 0 & 0 & 0 & $\varnothing$ & 8 & (8) & 8 & 8 & 8 \\
\hline \multirow{5}{*}{ 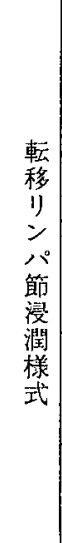 } & 1 & 0 & & & & & & $\begin{array}{l}0 \\
x \times x \times\end{array}$ & 0 & $x$ & & & & & \\
\hline & 2 & $\begin{array}{ll}0 \\
0\end{array}$ & $\square$ & & & $x$ & & $\begin{array}{l}00 \\
x \times x\end{array}$ & & $x$ & $x$ & & & & $x$ \\
\hline & 3 & $x$ & & 0 & & & & \begin{tabular}{l|l}
0000 \\
0 \\
$x x$
\end{tabular} & 0 & $x$ & $\begin{array}{l}00 \\
x \times x\end{array}$ & $\begin{array}{l}0 \\
x x\end{array}$ & & $\begin{array}{l}x \\
x\end{array}$ & $\begin{array}{l}x \\
x\end{array}$ \\
\hline & $4 \mathrm{C}$ & & 0 & $0:$ & & & & $\begin{array}{l}0000 \\
x \times\end{array}$ & $\begin{array}{l}0 \\
\Delta\end{array}$ & & $\begin{array}{l}0 \\
x \times x \times x\end{array}$ & 0 & & $x$ & $x$ \\
\hline & $4 \mathrm{D}$ & & & & & & $x$ & $\begin{array}{l}0 \\
x\end{array}$ & $x \times x$ & $x$ & $\begin{array}{l}x \times x \times \\
x \times \\
x \times\end{array}$ & & & & \\
\hline
\end{tabular}


表 8 原発单および転移巣の病理組織学的分化度と予後

\begin{tabular}{|c|c|c|c|c|c|c|}
\hline 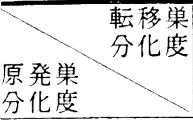 & $\mathrm{PN}(-)$ & $\mathrm{G}-1$ & $\mathrm{G}-2$ & $\mathrm{G}-3$ & $\mathrm{G}-4$ & $\mathrm{Ao} /$ 症例数 \\
\hline G-1 & $\begin{array}{l}00 \\
\square \times x \\
\times x \times\end{array}$ & $\begin{array}{l}00 \\
\times \times\end{array}$ & $\begin{array}{l}0 \\
x \times x\end{array}$ & $\begin{array}{l}0 \\
\times\end{array}$ & & $6 / 16$ \\
\hline $\mathrm{G}-2$ & $\begin{array}{l}00000 \\
00000 \\
00000 \\
00000 \\
00 \\
\times \times \times\end{array}$ & $\stackrel{0}{x \times x}$ & $\begin{array}{l}00000 \\
00000 \\
00000 \\
\square \\
\times \times \times \times \times \\
\times \times \times \times \times \\
\times\end{array}$ & $\begin{array}{l}00 \\
x \times x \times x \\
x \times\end{array}$ & & $40 / 68$ \\
\hline$G-3$ & $\begin{array}{l}00000 \\
\triangle \\
\times \times \times x\end{array}$ & & $\begin{array}{l}00 \\
\Delta \\
x \times x\end{array}$ & $\begin{array}{l}0000 \\
\triangle \\
\times \times \times \times \times \\
\times \times \times\end{array}$ & & $11 / 29$ \\
\hline$\overline{G-4}$ & $x$ & & & & & $0 / 1$ \\
\hline $\mathrm{Ao} /$ 症例数 & $29 / 42$ & $3 / 8$ & $18 / 38$ & $7 / 26$ & & $57 / 114$ \\
\hline
\end{tabular}

O: Ao $x$ : Dc $[$ : Do $\triangle:$ Ac

多かった。

頙部郭清術式:は患侧 TND を基本としたが，患側 PN (十)，対側 PN(ー) 症例での成績はよく流はかった。 一方同様な症例で患側 TND，対側 UNDを行った症例 は比較的成績がよかったが，対側 PN(ー）であったこ とから subclinical lymph node metastasis であったとは 考えにくく，選択的頸部郭清術を含む原発巣の十分な手 術が効果があったと思われた，郭清方法について:は，患

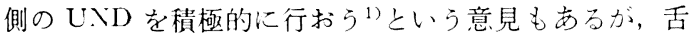
癌，口底癌では早期に遠位に Level 転移を起こしやすい 点 5,6$)$, 一次治療後に後発転移が起こった時点では転移 巣がリンパ節内の大部分を占め, 節外転移を起こす割合 が多いこどより，全頸部郭清を基本とし，原発巣の状 態により，T2の一部を含めて選択的頸部郭清を行う必 要があると考えられた。

最近, 組織学的覀性度評価を癌細胞についてと腫瘍一 宿主関係に分け, score をつけ，悪性度評価により行う試 みが多くなされており は後者の大きな要素を占めていると思われる。 Willen ${ }^{10)}$, Lund ${ }^{11)}$, Holm ${ }^{12)}$ などより悪性度評点が頸部転移の 頻度や子後と相関するといら所見が報告されて去り， McGavran ${ }^{13)}$ は喉頭癌における分析で frequency of metastasis $と$ type of invasive growth pattern が相関 寸ると報告し，山本ら ${ }^{14)}$ ，篠原ら ${ }^{4)}$ は口腔扁平上皮癌に おいて，原発单ならびに頸部転移柴の浸潤様式と頸部転 移の頻度, 予後との明確な関係を示した。しかし, 潜在 性の頸部りンパ節転移を子期する上では浸潤様式:は有用 ではあるが，必ずしも頸部転移とは相関しない結果 ${ }^{15)}$ 報告されており，また一方，術前の試験切除標本より手 術摘出材料の方が浸潤様式の grade は高い16) との報告
もあ门，評価は慎重を期寸必要があると思われた。われ われの結果では，浸潤様式の grade が高い症例では転移 頻度が高く，予後も覀い傾向があったが，一方，浸潤様 式 2,3 でも頸部転移症例も多く，子後も必方しも良く はなく，浸潤様式 $4 C^{\prime} ， 4 \mathrm{D}$ でも頸部転移せず，予後良 好の症例もかなり及られた。亦なわち、この浸潤様式の 要素たけで判断することは多くの false positive, false negative を生むことになると思われた。また原発巣と頸

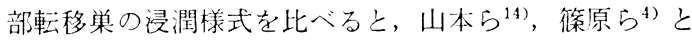
同様に頸部転移兽の方が幾分高度になっているようであ り，頸部転移单で $4 \mathrm{D}$ 老示与症例:生存が $3 / 16$ 例(18.8 \%) と著明に低く， retrospective に浸潤様式を考えるこ とは重要なことと思われた。しかし，初回治療前にこの 因子のみを应大して評価し，治療方針をたてることは， 他に多くの予後因子があることからも一面的であり，慎 しまなければならないと思わ机た。

リンハ節転移の進展:よ，一般に周縁洞より䯋洞人。乙 してリン・節全体を置换した後にリンバ節被膜を破壊 し，周囲組織へ浸潤する1，17といわれており，また場合 により直接皮質や傍皮質などの奏質八浸潤して行くもの もある(1)といわれている。わ响れの結果では，リンパ 節転移進展度 $\mathrm{D}$ 型(佐藤らのい5全体置換型7), 新垣のい 5 Entire node-metastatic type ${ }^{1)}$ ) が最も多く, 次にり ン八節全体に散在性に転移進展を示守 $\mathrm{E}$ 型が多く，転移 初期を示与 $\mathrm{A}$ 型， $\mathrm{B}$ 型， C型はわずかにみられるのみで あり, 本間 ${ }^{15)}$, 新垣 ${ }^{1)}$, 佐藤らうの所見が裏付けられた。 節外転移ハターンはO型（節内転移）と 1，2，3 型（節 外転移）が同数であり，3型，特にD-3 型を示与症例が 多かった。転移進展度と節外転移パターンを組又合わせ ると D-O 型，D-3型すなわちりンバ節全体が転移䉓に 
占められており，節外転移をしているものは被膜の大半 が腫瘍で占められているものが多かった。 Tocker ${ }^{17}$ のい う初期節外型の転移は2 例のみであり, 本間 ${ }^{18)}$, 山本 ${ }^{14)}$, 新垣 ${ }^{1)}$ の結果に類似しており, 転移巣の多くは早期にり ンパ節内で全体に抾がり，あるものは節外転移へと移行

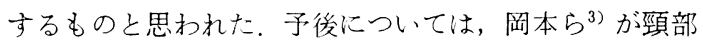
転移死と遠隔転移死の大半が節外浸潤症例であったと述 べ, Nooneら ${ }^{19)}$ の結果では頸部転移症例で 5 年生存率が 節外転移症例飞おいて節内転移症例の $1 / 2$ 以下であった ことが示され，また，Snow ら ${ }^{20)}$ は頸部郭清手術後の制 御率について, 転移リンパ節の数よりも節外転移の有無 がより反映するという興味深い報告を行っている．われ われの結果では、リンパ節内全体に転移の抎がった D$0, \mathrm{E}-0$ 型は予後に関してはあまり良くはなく，節外転 移を示す C-2, D-1, D-2, D-3， E-2， E-3 型はいずれ も著明に悪かった。これらをまとめると、リンパ節転移 進展度と節外転移バターンは最も重要な予後因子の一つ と思われ，これに転移リンバ節の浸潤様式を組及合わせ ることより情報量が增兄るようであり，D1〜3型で浸潤 様式 $4 \mathrm{D}$ 型の 10 例には制御された症例がなかったといら 明確な結果を示した。浸潤様式 1〜 4C 型の特徵はあき らかではなかったが，いずれにしろ、リンパ節転移進展 度節外転移ハターン，転移リンパ節浸洞様式を組及合せ ることは, 術後の頸部再発, 遠隔転移の可能性を子期す る上できわめて有効と思われた。

分化度と頸部転移，予後については古く Broder の口 唇癌で分化度と予後が相関するといら報告があり, 新 垣 ${ }^{1)}$ は口腔領域癌で Grade I 28.5\%, Grade II 37.0\%, Grade III 50.0\%の頸部転移率を報告し，Eneroth ${ }^{21)}$ は口 蓋癌で分化度が低い程転移率が上昇すると述べ，小野は 舌癌において分化度が治療前リンバ節転移, 潜在性りン 八節転移に関連があり，予後と関保深いと報告した。一 方，花沢ら ${ }^{15)}$ は分化度とリンハ節転移との間に有意の相 関はなかったと述べている。5生率では, Noone ら ${ }^{19)}$,

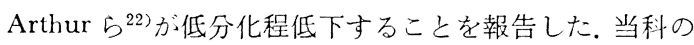
結果では, 頸部郭清術施行症例について原発巣の分化度 でみると，転移率は Grade I 62.5\%, Grade II 62.7\%, Grade III 37.9\%と差がなく, 制御率では Grade II 59.7 $\%$ ，Grade III 37.9\% と差を示した。転移リンバ節の分 化度は原発䊆のそれと類似していたが，岸野 23 が述べて いるように転移りンパ節の方が低分化を示すようであ り，原発巣と転移巣がともに Grade III であった13症例 中, 制御症例が 4 例と少なく, 分化度も予後に関連して いると思われた。

\section{結}

\section{論}

1981〜1988年の8 年間における頸部郭清術施行症例の なかで 1 次症例で扁平上皮癌の 148 例について検討し，
以下の結果を得た.

1. 部位は舌 68 例, 下顎雨肉 39 例, 上顎 13 例（口蓋 2 例), 口底 15 例, 煩粘膜 7 例, 口峡咽頭 5 例および口唇 1 例であった。

2. 原発巣別の転移部位は, 舌が上内深頸リンパ節が 最も多く, 下顎粜肉が顎下リンパ節, 口底が上内深頸と 買下，上顎が上内深頸で対側転移が多くみられた。

3. 転移リンパ節個数別の制御率では，1個が $48.6 \%$, 2 個が $43.5 \% ， 3$ 個が54.5\%であったが，4 個以上は 5.6 \%と低かった。

4. 転移リンパ節 Level 分類別の制御率は Level 1 が $65.4 \%$, Level 2 が $29.0 \%$, Level 3 が $33.3 \%$ ，および Level 4 が0\%であり, Level 1 が高く, Level 4 が低い結 果であった。

5. PN $(+),(-)$ 別では, 患側 $\mathrm{PN}(-)$, 対側 $\mathrm{PN}$ (一) が最も制御率が高く, 次が患側 $\mathrm{PN}(+)$, 対側 PN （一）であり，患側 $\mathrm{PN}(+)$, 健側 $\mathrm{PN}(+)$ の症例は低 かった。

6. 病理組織学的浸潤様式と予後の関係では, 原発巣 では 4C，4D 型が子後が悪く, 転移巣では 4D 型が多 くなり予後も悪かった。

7. リンバ節転移進展度は D 型 (全体置換型)， $\mathrm{E}$ 型 (び漫散在型) が多く, 節外転移パターンはO 型（節内 転移)，1，2，3 型 (節外転移) が同数であり， D, E 型 で節外転移を示す症例の予後が悪かった。

8. 病理組織学的分化度は原発巣, 転移巣ともに G-3 が予後の悪い傾向であった。

\section{引用 文 献}

1）新垣 晋. 口腔領域覀性腫瘍の頙部リンパ節転 移に関与る臨床病理学的研究. 日口外誌 25 : 784-797 1979.

2）牧野総太郎：頸部転移と予後. JOHNS 6：1871911990.

3) 隹本学, 大関 悟, 他：口腔癌における钼部 郭清街施行例の検討。頸部リンパ節耺移栚相と 予後。日口外誌 31：554-562 1985 .

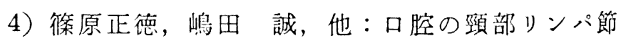
耺移に関する臨休的・病理組織学的検討。頭頸 部腫㽷 16: 113-118 1990.

5) 堀越勝, 草間幹夫, 他: 下顎透肉扁平上皮癌 の臨床的研究. III 所属リンパ節転移症例の原発 单の臨床像および病理組織像について, 頭頸部 腫瘍 16：119-125 1990 .

6) 天津睦郎, 井上健造: 治療方針々その選択. 手 術治療の立場から. JOHNS 6: 213-216 1990.

7) 佐藤微, 渡部亮夫, 他 : 口腔瘦および上靧洞 癌の頸部郭清例における臨床的, 病理組織学的 検討。口科誌 38：1282-1282 1989.

8）松浦秀博，深野英夫：選択的郭清の是非。とく 
に口腔底扁平上皮瘦について. JOHNS 6: 277-283 1990.

9) Anneroth, G., Batsakis, J., et al.: Review of the literature and a rcommended system of malignancy grading in oral squamous cell carcinoma. Scand J Dent Res 95: 229-249 1987.

10) Willén, R., Nathanson, A., et al.: Squamous cell carcinoma of the gingiva. Histological classification and grading of malignancy. Acuta Otolaryngol 79: 146-154 1975.

11) Lund, C., Sogaard, H., et al.: Epidermoid carcinoma of the tongue. Histologic grading in the clinical evaluation. Acta Radiologica Therapy Physics Biology 14: 513-521 1975.

12) Holm, L.E., Lundquist, P.G., et al.: Histological grading of a malignancy in squamous cell calcinoma of the oral tongue. Acta Otolaryngol 94: 185-192 1982.

13) McGavran, M.H., Bauer, M.C., et al.. The incidence of cervical lymph node metasasis from epidermoid carcinoma of the larynx and their relationship to certain characteristics of the primary tumor. Cancer 14: 55-67 1961.

14）山本悦秀, 宮川明, 他：口膑粘膜癌の所属り ンパ節内浸潤增殖像に関する研究。特に原発单 の尰疾の浸潤様式との関連について，日口外誌 30: 1824-1833 1984.
15）花沢秀：舌癌に打ける組織学的恶性度 (Willén 分類変法) と頙部リンパ節転移との関 連性. 日癌治 21：34-41 1986.

16) Fisher, H.R.: Grading of biopsies of laryngeal carcinomas by multiple criteria. Can J Otolaryngol 4: 881-884 1975.

17) Tocker, C.: Some observation on the deposition of metastatic carcinoma with in cervical lymph nodes. Cancer 16: 364-374 1963.

18）本間義郎：口腔癌の钼部りンパ節転移に関卞る 研究. 日口外誌 28: 1667-1684 1982.

19) Noone, R.B., Bonner, J.H. et al.: Lymph node metastases in oral carcinoma. A correlation of histopathology with survival. Plast Reconstr Surg 53: 158-166 1974.

20) Snow, G.B., Annyas, A.A., et al.: Prognostic factors of neck node metastasis. Clin Otolaryngol 7: 185-192 1982.

21) Eneroth, C.M, Hjertman, L., et al.: Squamous cell carcinomas of the palate. Acta Laryngol 73: 418-427 1972.

22) Arthur, J.F., Fenner, M.L.. The influence of histological grading on prognosis in carcinoma of the tongue. (A computer analysis of 299 case) Clin Radiol 17: 384-396 1966.

23）岸野彔雄：癌の転移。中外医学社, 東京, 1973, 7-7面. 